\title{
The Effect Of Perception Of Trust, Perception Of Ease Of Use, Perception Of Benefits, Perception Of Risk And Perception Of Service Quality On Interest In Using Mobile Banking Bank Independent In Bekasi City
}

\author{
Okky Natalia $^{1 *}$, Rini Tesniwati ${ }^{2}$ \\ ${ }^{1,2}$ Program Magister Perbankan \\ Pasca Sarjana Universitas Gunadarma, Indonesia \\ Jl. Margonda Raya No. 100, Depok 16424, Jawa Barat. \\ ${ }^{*}$ Corresponding Author: \\ Email: okkynatalia@gmail.com
}

\begin{abstract}
.
The purpose of this study was to explain and analyze the effect of perceived trust, perceived convenience, perceived risk, perceived service quality on interest in using mobile banking at Bank Mandiri in Bekasi city. The research methodology used is a quantitative approach. The sample used is the customer of Bank Mandiri Bekasi City as many as 100 respondents. The data collection instrument used primary data. Primary data was obtained by using a questionnaire. Analysis of the data used in this study is multiple linear regression test, classical assumption test, autocorrelation test, multicollinearity test, heteroscedasticity test, determinant test, $t$ test and $f$ test with the help of SPSS version 24. The results showed that partially or simultaneously the perception of trust, perception of convenience, perception of risk, perception of service quality have a significant effect on interest in using bank Mandiri mobile banking in the city of Bekasi.
\end{abstract}

Keywords: Perception of Trust, Perception of Ease of Use, Perception of Benefits, Perception of Risk, Perception of Service Quality and Interests

\section{INTRODUCTION}

One form of e-banking service is mobile banking. Mobile banking or better known as m-banking is a banking facility or service using mobile communication tools such as mobile phones, with the provision of facilities for banking transactions via SMS (short messages) on mobile phones. With the existence of cellphones and mobile banking services, banking transactions that are usually done manually, meaning that activities previously carried out by customers by visiting the bank, can now be done without having to visit bank outlets, only by using a cellphone the customer can save time and costs Service mobile banking provides convenience to customers to conduct banking transactions such as check balances, transfer between accounts, and others (Syaefullah \& Mubiyantoro, 2015). Mobile banking provides benefits to both banks and customers. Among them for the bank are business expansion, customer loyalty, revenue and cost improvement, competitive advantage, new business model and fee base income. In addition, the benefits for customers include providing convenience and 
speed, transactions anywhere and anytime that can be done saving costs and time, transactions that can be carried out such as checking balances, transfers, payments, and purchases without going out of the house or coming to the bank. access a smartphone (Habibi, 2014).

The benefits and ease of using this mobile banking application in fact do not always go hand in hand with the enthusiasm (interest) of consumers (customers) to use the application. According to Sunendar (2011) interest is a combination of desire and willingness that can develop. A person will perform a behavior if he has the desire or interest to do it. Interest in using a new technology in this case mobile banking can be influenced by several factors. Among them are the customer's own perceptions of the mobile banking application.Perception of the benefits (perceived usefulness) is the belief that one of the benefits arising from the use of a technology. Perceived ease of use (perceived ease of use) is the extent to which a person believes that using a free technology from a business, which means it is easy to use. Meanwhile, the perception of risk is a consumer's feeling of uncertainty about the decisions he makes (Laksana, 2015). The perception of trust according to Lau and Lee (in Anwar, 2018) states that as an individual's willingness to depend on other parties with certain risks. This willingness arises because of the individual's understanding of the other party based on his past, the expectation that the other party will make a positive contribution (although there is also the possibility of the other party making a negative contribution).

In addition, the customer's perception of the mobile banking application is the quality of service. The quality of services provided by mobile banking to customers is of course an added value to customer interest, the better the quality of services provided by mobile banking, the more people who choose to make transactions through mobile banking. On the other hand, if the quality of service provided by mobile banking is poor, people will not choose to make transactions using mobile banking. There are not a few financial institutions that offer attractive facilities that suit customer needs and make customers choose the bank. Service quality can be seen from direct evidence, reliability, responsiveness, assurance, and certainty factors (Tjiptono, 2009)Perception of utility usage significantly influence the interest of transactions (Maulana et al., 2019). Customer perception has a significant effect on satisfaction, satisfaction has a significant effect on usage. Customer perception has a significant influence on usage. Satisfaction has a role as an intervening variable in the research model (Sanawiri, 2019) . Perceived benefits, perceived ease of use and confidence positive and significant effect on the interest for the use of electronic money instruments, while the negative effect of risk perception variables but not significant interest in using electronic money instruments (Yogananda \& Aerospace, 2017).

Perception ease of use positive effect on the interest in using an e-wallet. Perceived benefits have a positive effect on interest in using e-wallet. Perception of risk has a negative effect on interest in using e-wallet. Trust has a positive effect on 
interest in using e-wallet. Perceived ease of use, perceived usefulness, perceived risk, and trust together have a significant effect on interest in using e-wallet (Siti Rodiah \& Inaya Sari Melati, 2020 . Perceived benefits, perceived ease of use, and the perception of risk is partially significant effect on the decision to use electronic money based QRIS (Ning et al., 2021).Ease of use and no significant positive effect on the use of financial technology (fintech) with interest as mediation. Positive effectiveness and significant impact on the use of financial technology (fintech) with interest as mediation. Risk positive and not significant to the use of financial technology (fintech) with the mediation of interest (Setiawan et al., 2020) . Perception of Ease of Use, Perception of Usability, Perception of Trust and Perception of Benefits simultaneously affect customer interest (Romadloniyah \& Prayitno, 2018). Perceived ease of use has a positive effect on perceived usefulness and both have a positive effect on attitudes. Another result of this study shows that the perception of risk has a negative effect on beliefs and attitudes. The results also show that trust and attitude have a positive effect on online shopping intentions (Karnadjaja et al., 2018). Perception of ease of use has a positive and significant effect on intention to use Mobile Commerce. Perceived benefits have a positive and significant effect on intentions to use Mobile Commerce. Risk perception has a positive and significant effect on intentions to use Mobile Commerce (Dewi \& Warmika, 2016)

Perceived benefits, perceived ease of use, and level of trust have a positive and significant effect on student interest in using electronic money (Pratama \& Suputra, 2019). There is a positive and significant effect between perceptions of ease of use on interest, there is a positive and significant effect between trust and interest, there is a positive and significant effect between service features on interest (Syafitri, 2020). P ersepsi ease of use, trust, and knowledge affect the interest in using E-Banking in transactions on SMEs (Rizky, 2018).Perceived usefulness, perceived ease of use, perceived risk and perceived suitability have a significant effect on interest in using mobile banking, while the one with the most dominant influence is perceived conformity (Laksana, 2015). Perceived benefits, perceived convenience and perceived security have a significant effect on customer interest in using mobile banking (Pranoto \& Setianegara, 2020). Perceived benefits, perceived ease of use, security have a significant positive effect on the use of E-banking, while the perception of risk has a significant negative effect on the use of E-banking (Oktabriantono et al., 2017).

Perception of ease of use and perception of suitability affect attitudes to use mobile banking services .

On the other hand, the constructs of perceived usefulness and perceived risk have no effect on attitudes towards the use of mobile banking services. The implications of this research are relevant for bank management and mobile banking analysts to pay attention to the ease of use and suitability factors in implementing and developing mobile banking transactions in their banking system (Oktabriantono et al., 2017). Different research results are shown by Susanti (2015), which states that 
perceived usefulness has no significant effect on interest in using mobile banking. Based on the description of the problems above, the researchers are interested in conducting research with the title " The Influence of Perceived Trust, Perceived Ease of Use, Perception of Benefits, Perception of Risk and Perception of Service Quality on Interest in Using Bank Mandiri Mobile Banking in Bekasi City "

\section{METHODS}

This research was conducted at Bank Mandiri in the city of Bekasi in February 2021 with customers using mobile banking as the research population and a sample of 100 respondents. The analytical tool used is multiple linear regression by fulfilling the requirements of normality test and classical assumption test. The variables of this study include the perception of trust, the perception of convenience, the perception of benefits, the perception of risk and the perception of service quality and interest. The operational concepts and definitions are as follows:

\begin{tabular}{|c|c|c|c|}
\hline No & Variabel & Konseptual & Operasional \\
\hline 1 & $\begin{array}{l}\text { Perceived } \\
\text { Trust }(X 1)\end{array}$ & $\begin{array}{l}\text { According to Lau } \\
\text { and Lee (in Anwar, } \\
\text { 2018) define trust as } \\
\text { an individual's } \\
\text { willingness to } \\
\text { depend on other } \\
\text { parties with certain } \\
\text { risks. }\end{array}$ & $\begin{array}{l}\text { Trust as a psychological condition which } \\
\text { consists of 1) Being trustworthy, 2) Putting } \\
\text { the customer's interests first, 3) Maintaining a } \\
\text { good name and being highly committed, 4) } \\
\text { Trusting the information provided, 5) And } \\
\text { paying attention to the condition of the } \\
\text { customer. (Koufaris, 2002) }\end{array}$ \\
\hline 2 & $\begin{array}{l}\text { Perceived } \\
\text { Ease of Use } \\
(X 2)\end{array}$ & $\begin{array}{l}\text { A person's level of } \\
\text { belief that a certain } \\
\text { technological system } \\
\text { can be used easily or } \\
\text { without effort } \\
\text { (Ayyagari, 2006). }\end{array}$ & $\begin{array}{l}\text { This concept includes the clarity of the } \\
\text { purpose of using IT and the ease of using the } \\
\text { system for purposes according to the wishes } \\
\text { of the user in the form of: 1) Easy to Learn } \\
\text { (information technology is very easy to learn), } \\
\text { 2) Controllable (can be controlled), 3) Clear \& } \\
\text { Understandable (clear \& understandable). ), 4) } \\
\text { Flexible, 5) Easy to Become Skillful, 6) Easy } \\
\text { to Use }\end{array}$ \\
\hline 3 & $\begin{array}{l}\text { Perception of } \\
\text { Benefits }(X 3)\end{array}$ & $\begin{array}{l}\text { According to } \\
\text { Jogiyanto (2007) } \\
\text { perceived benefits } \\
\text { are defined as the } \\
\text { extent to which a } \\
\text { person believes that } \\
\text { using a technology } \\
\text { will improve his or } \\
\text { her job performance. }\end{array}$ & $\begin{array}{l}\text { Technology users will have an interest in } \\
\text { using technology (behavioral interest) if they } \\
\text { feel the technology system is useful. The } \\
\text { benefits of Information Technology are 1. Can } \\
\text { be accessed anywhere and anytime. } 2 \text {. More } \\
\text { effective to use. } 3 \text {. Increase productivity. } 4 \text {. } \\
\text { Faster. 5. Help performance. }\end{array}$ \\
\hline 4 & $\begin{array}{l}\text { Risk } \\
\text { Perception } \\
(X 4)\end{array}$ & $\begin{array}{lr}\text { Dowling } & \text { in Farizi } \\
\text { and } & \text { Syaefullah } \\
(2014) & \text { risk } \\
(\text { perceived risk ) is a } \\
\text { negative consumer } \\
\text { perception of a }\end{array}$ & $\begin{array}{l}\text { Risk greatly affects the level of trust. The } \\
\text { smaller the risk of an individual, the greater } \\
\text { the level of trust, and vice versa. Information } \\
\text { technology risks in banking include } 1 \text {. There } \\
\text { may be a risk of theft } 2 \text {. Requires large costs. } \\
\text { 3. There may be a risk of fraud }\end{array}$ \\
\hline
\end{tabular}




\begin{tabular}{|c|l|l|l|}
\hline No & Variabel & Konseptual & Operasional \\
\hline 5 & $\begin{array}{l}\text { Perception of } \\
\text { that are based on } \\
\text { negative results and } \\
\text { allow the results to } \\
\text { be real. }\end{array}$ & $\begin{array}{l}\text { Kotler (in Umar, } \\
\text { Quality }(X 5) \\
\text { that is profitable in a } \\
\text { group or entity, and } \\
\text { offers satisfaction } \\
\text { even though the } \\
\text { results are not tied to } \\
\text { a physical product. }\end{array}$ & $\begin{array}{l}\text { Service quality can be expressed as a } \\
\text { comparison between the services expected by } \\
\text { consumers and the services they receive. } \\
\text { Consumer expectations in the form of 1. } \\
\text { Assurance 5. Empathy }\end{array}$ \\
\hline 6 & $\begin{array}{l}\text { Interest in } \\
\text { using mobile } \\
\text { banking }(Y)\end{array}$ & $\begin{array}{l}\text { According to Habibi } \\
\text { and Zaky (2015), } \\
\text { interest is one of the } \\
\text { aspects of the human } \\
\text { psyche that can } \\
\text { encourage them to } \\
\text { achieve goals. }\end{array}$ & $\begin{array}{l}\text { Interest in the use of information technology } \\
\text { is acceptance of the use of technology based } \\
\text { on perceptions of the ease of using } \\
\text { information technology and considering its } \\
\text { benefits. A person's interest can be expressed } \\
\text { by 1) Interest in using, 2) Interest in using it } \\
\text { regularly, 3) Suggesting others to use internet } \\
\text { banking }\end{array}$ \\
\hline
\end{tabular}

\section{RESULT AND DISCUSSION}

The results of the pre-requisites of the main test of multiple linear regression indicate that the data has a normal distribution, this is evidenced by the line that describes the actual data following the diagonal line. While the heteroscedasticity test shows that the regression model does not have heteroscedasticity. This is evidenced that there is no clear pattern, as well as the dots spread. The regression model does not occur multicollinearity. This is evidenced by the VIF value of less than 10 and the tolerance value of more than 0.1.Regression analysis showed that the variables $p$ ersepsi trust $\left(X_{1}\right) t_{\text {count }}>t$ table $(6.705>1.981)$ which means that the perception of trust variables $\left(\mathrm{X}_{1}\right)$ has a partial effect on the interests of customers using mobile banking. For the perceived ease of use variable $\left(\mathrm{X}_{2}\right) \mathrm{t}_{\text {count }}>$ $t_{\text {table }}(3.353>1.981)$ which means that the perceived ease of use variable $\left(\mathrm{X}_{2}\right)$ has a partial effect on customer interest in using mobile banking. The perception of the benefits for the variable $\left(\mathrm{X}_{3}\right) \mathrm{t}_{\text {count }}>\mathrm{t}_{\text {table }}(3.052>1.981)$ which means that the perception of the benefits of a variable $\left(\mathrm{X}_{3}\right)$ has a partial effect on the interests of customers using mobile banking. For the risk perception variable $\left(\mathrm{X}_{4}\right) \mathrm{t}_{\text {count }}>$ $\mathrm{t}_{\text {table }}(2.583>1.981)$ which means that the risk perception variable $\left(\mathrm{X}_{4}\right)$ has a partial influence on customer interest in using mobile banking .

For the service quality perception variable $\left(\mathrm{X}_{5}\right) \mathrm{t}_{\text {count }}>\mathrm{t}_{\text {table }}(3,046>1,981)$ which means that the service quality perception variable $\left(\mathrm{X}_{5}\right)$ has a partial influence on customer interest in using mobile banking. The results of data analysis on perceptions of trust, perceptions of ease of use, perceptions of benefits, perceptions of 
risk and perceptions of service quality partially or simultaneously affect the interest in using bank Mandiri mobile banking in the city of Bekasi. The results of the regression analysis test showed positive results in each value of the independent variable, this means that every increase in the independent variable will increase interest in using mobile banking. While the results of the correlation test show that most of the interest in using mobile banking is indeed influenced by the independent variable.This result is supported by the respondent's description of each independent and dependent variable. Customers consider that Bank Mandiri Kota Bekasi can be trusted, prioritizes customer interests, maintains good reputation and is highly committed, trusts the information provided and pays attention to customer conditions.

Mandiri mobile banking is easy to learn, can be controlled at any time, has clear features, can make transfer transactions without having to go to a branch office, to be skilled at using Mandiri Mobile banking does not take a long time and has a simple menu. Customers consider that using mobile banking at Bank Mandiri Bekasi City can be accessed anywhere and anytime, more effectively used, increases productivity, is faster and helps performance. Customers consider using mobile banking at Bank Mandiri in Bekasi there is a risk of theft, requires large fees and there is a possibility of fraud risk. Customers consider using Mandiri bank mobile banking to have a complete, reliable menu, have responsive customer service, transact using Mandiri Mobile banking to provide a sense of security, provide notification of every transaction made by customers. In terms of interest in using mobile banking, customers have a high interest in using mobile banking at Bank Mandiri. Respondents will be interested in using independent mobile banking regularly and suggest others to use internet banking. The results of this study support research conducted by Pranoto (2020) which states that perceptions of benefits, convenience, security have a significant effect on customer interest in using mobile banking at PT Bank Rakyat Indonesia (Persero) Tbk Semarang Pandanaran Branch.

The results of this study are in line with the opinion of Sunendar (2011) which states that interest is a combination of desire and willingness that can develop. A person will perform a behavior if he has the desire or interest to do it. Interest in using a new technology in this case mobile banking can be influenced by several factors. Among them are the customer's own perceptions of the mobile banking application.One form of e-banking service is mobile banking. Mobile banking or better known as m-banking is a banking facility or service using mobile communication tools such as mobile phones, with the provision of facilities for banking transactions via SMS (short messages) on mobile phones. With the existence of cellphones and mobile banking services, banking transactions that are usually done manually, meaning that activities previously carried out by customers by visiting the bank, can now be done without having to visit bank outlets, only by using the customer's cellphone can save time and costs. Service mobile banking provides convenience to customers to conduct banking transactions such as check balances, 
transfer between accounts, and others (Syaefullah \& Mubiyantoro, 2015).Mobile banking provides benefits to both banks and customers. Among them for the bank are business expansion, customer loyalty, revenue and cost improvement, competitive advantage, new business model and fee base income. In addition, the benefits for customers include providing convenience and speed, transactions anywhere and anytime that can be done saving costs and time, transactions that can be carried out such as checking balances, transfers, payments, and purchases without going out of the house or coming to the bank. access a smartphone (Habibi, 2014).

\section{CONCLUSION}

Based on the results of the research on the effect of perceived trust, perceived ease of use, perceived benefits, perceived risk and perceived service quality on using bank Mandiri mobile banking in Bekasi city, the following conclusions were drawn:

1. Perception of trust has an effect on interest in using Mandiri bank mobile banking in the city of Bekasi.

2. Perceptions of ease of use affect the interest in using Mandiri bank mobile banking in the city of Bekasi.

3. Perceptions of benefits affect the interest in using bank Mandiri mobile banking in the city of Bekasi.

4. Perception of risk has an effect on interest in using Mandiri bank mobile banking in the city of Bekasi.

5. Perceptions of service quality affect the interest in using Mandiri bank mobile banking in the city of Bekasi.

\section{ACKNOWLEDGMENTS}

The authors are grateful to previous research. And further research is expected to be able to develop this research, for example by using other methods and adding other variables not examined in this study.

\section{REFERENCES}

[1] Dewi, NMAP, \& Warmika, IGK (2016). This study aims to determine the effect of perceived ease of use, perceived benefits and perceived risk on intention to use. 5 (4), 2606-2636.

[2] Habibi, M. and AZ (2014). The Influence of Trust, Perceived Usefulness, Perception of Ease, and Perception of Convenience on Interest in Using Islamic Mobile Banking. Scientific Journal, 3 (1).

[3] Karnadjaja, CC, Tulipa, D., \& Lukito, RSH (2018). The Influence of Perceived Risk, Benefits, and Ease of Use on Online Shopping Interests Through Trust and Attitudes To Zalora Consumers In Surabaya. Scientific Studies of Management Students, 6 (2), 116-130. http://journal.wima.ac.id/index.php/KAMMA/article/view/1779

[4] Laksana, G. (2015). influence perceptions of usefulness, perceived ease of use, perceived risk and perceived suitability for interest in using mobile banking (study on 
customers of Bank Rakyat Indonesia (BRI) branch office in Rembang, Central Java). Journal of Business Administration S1 Universitas Brawijaya, 26 (2), 86309.

[5] Maulana, R., Iskandar, I., \& Mailany, M. (2019). The Effect of Mobile Banking Usage on Customer Interest in Transactions Using the Technology Acceptance Model. Cyberspace: Journal of Information Technology Education, 2 (2), 146. https://doi.org/10.22373/cj.v2i2.4161

[6] Ningsih, HA, Sasmita, EM, \& Sari, B. (2021). The Influence of Perceived Benefits, Perception of Ease of Use, and Perception of Risk on Decisions to Use Electronic Money (QRIS) in Students. Journal of IKRA-ITH Economics, 4 (1), 1-9.

[7] Oktabriantono, AP, Sulindawati, N. luh GE, \& Dewi, PEDM (2017). The Influence of Perceived Usefulness, Perceived Ease of Use, Security, and Risk Perception on the Use of E-banking on Undergraduate Students of the Faculty of Economics, Ganesha University of Education. E-Journal S1 Ak Ganesha University of Education , 8 (2), 110 .

[8] Pranoto, MO, \& Setianegara, RG (2020). Analysis of the Effect of Perceived Benefits, Perceived Ease, and Security on Customer Interest in Using Mobile Banking (Case Study at PT Bank Rakyat Indonesia (Persero) Tbk Semarang Pandanaran Branch Office). Keunis Scientific Magazine, 8, 1-9.

[9] Pratama, AB, \& Suputra, IDGD (2019). The Effect of Perceived Benefits, Perceived Ease of Use, and Level of Trust on Interest in Using Electronic Money. E-Journal of Accounting, 27, 927. https://doi.org/10.24843/eja.2019.v27.i02.p04

[10] Rizky, N. (2018). The Influence of Perceived Ease of Use, Trust, and Knowledge on Interest in Using E-Banking in Transactions with MSMEs in Buleleng District. JIMAT (Accounting Student Scientific Journal) Ganesha University of Education, 9 (2), 191-202.

[11] Romadloniyah, AL, \& Prayitno, DH (2018). The Influence of Perceived Ease of Use, Perception of Usability, Perception of Trust, and Perception of Benefits on Customer Interest in Using E-Money at Bank Bri Lamongan. Journal of Accounting, 3 (3), 699. https://doi.org/10.30736/jpensi.v3i3.163

[12] Sanawiri, B. (2019). The Effect of Consumer Perception and User Satisfaction on the Use of M-Wallet. 9 (2), 160-173.

[13] Setiawan, A., Rofiningun, S., \& Patma, K. (2020). The Influence of Perceived Ease of Use, Effectiveness, Risk on Interest and Use of Financial Technology (Fintech) With Interest as a Mediation Variable. Journal of Regional Accounting and Finance, 15 (2), 35-48. https://doi.org/10.52062/jakd.v15i2.1623

[14] Siti Rodiah \& Inaya Sari Melati. (2020). The Effect of Ease of Use, Benefit, Risk, and Trust on Interest in Using E-wallet on Millennial Generation in Semarang City Faculty of Economics, Semarang State University, Indonesia Abstract. Journal of Economic Education and Entrepreneurship, 1 (2), 66-80.

[15] Syaefullah, \& Mubiyantoro, A. (2015). The Influence of Perceived Usefulness, Perceived Ease of Use, Perception of Appropriateness, and Perception of Risk on Attitudes to Use Mobile Banking (Case Study at Bank BRI Malang City). Dk, 53 (9), 1689-1699. 
[16] Shafitri. (2020). Trust, Features To The Interests Using Financial Technology (Fintech) In Ovo Application (Case study Students UPGRIS Force FEB 2016-2019). Unissula Student Scientific Conference (Kimu), 4, 1008-1036.

[17] Yogananda, AS, \& Dirgantara, IMB (2017). The Influence of Perceived Benefits, Perceived Ease of Use, Trust and Perceived Risk on Interest in Using Electronic Money Instruments. Diponegoro Journal of Management, 6 (4), 1-7. 